\title{
The Impact of Community Conflict on Tourists' Behaviour in Sri Lanka: A Case of Madunagala Hot Spring Area
}

\section{Chandima Bogahawatta}

\section{Abstract}

Tourism that is engaged with local communities offers a multitude of opportunities and economic benefits to the community. When the local communities do not get sufficient economic benefits from tourism, their competitive reactions to earn more economic benefits create conflicts. A conflict occurs when the goal of an individual or a group is interrupted by another group. The dissatisfactions of tourists can affect tourism-related conflicts of a particular destination. This paper is based on a qualitative study done at Madunagala Hot Spring to identify the background of community conflicts due to tourism and how they influence tourists' behaviours. The local community which was investigated during the study includes vendors at Madunagala Hot Springs. Due to the lack of economic benefits, competition occurs between permeant shop vendors and temporary shop vendors when dealing with tourists. The study is based on the objectives to identify how negative impacts of conflicts on tourists' behaviours can be reduced through the findings of the study. Primary data was gathered by a three day field observation at the site, and personal interviews with vendors and domestic tourists were done under the unstructured interviewing technique. The content analysing method was adapted for data analysis. Tourist behaviours vary due to vendors' conflicts that create disasatisfaction among tourists. Conflicts can be reduced by introducing new selling techniques such as product diversification, and vendors should be aware of tourism. Attitudes of tourists also should be improved to create a conflict-free environment at the site.

Keywords: community conflicts, tourists' behaviour, tourist destination, tourism vendors
Department of

Archaeology

University of Kelaniya

dr.chandima@kln.ac.lk

(1D https://orcid.org/ 0000-00034248-611X

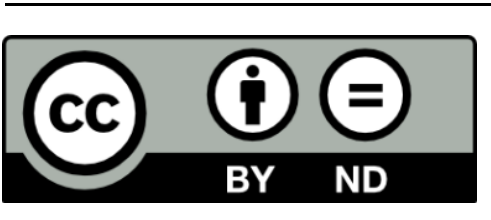

This article is published under the Creative Commons CC-BY-ND License (https://creativecommons.org/licenses/by-nd/4.0/). This license permits to use, distribute, and reproduce the contents of the publication for commercial and non-commercial purposes, provided that the original work is properly cited and is not changed anyway. 


\section{Original Article}

\section{INTRODUCTION}

The success of tourism development always depends on the goodwill and the cooperation of the local community (Nagarjuna, 2015). Ashley and Roe (1998) have discussed the local community's involvement in the tourism industry. According to the authors, the local community can be involved in various ways such as employment in the tourism sector, including local entrepreneurship, leasing out land for tourism, creating partnership agreements with tourism operators, and active participation in planning and decision making related to tourism (Ashley \& Roe, 1998). The local community should be benefited from tourism by creating opportunities for their improvement. Even tourism creates considerable positive benefits on the local community, and tourism can also negatively impact the local community, including; negative sociocultural, environmental and economic aspects (Iran Nomand Tours, 2020). Displacement of local people to make way for tourism facilities, depletion of local resources, increase in the cost of living and commercialisation of culture are the heightened reasons for the negative impacts on local communities by Ashley and Roe (1998), which may create irritation on local peoples' mind regarding tourism as per the view by Imran Nomand Tours (2020).

Mahapelessa Hot spring, known as Madunagala Hot Spring, is one of the significant places that has grabbed tourist attraction in the Southern province. The Ruhunu Tourist Bureau maintains it. The residents started to involve directly and indirectly with the activities related to tourism by selling local foods and products for travellers by keeping temporary retail shops on the roadsides. The Southern provincial council developed the site in 2008 with proper vehicle parking facilities. The retail shops have been moved from the roadside, and shop holders could get permanent stoles in the building established in the vehicle park. Through the Ruhunu Tourist Bureau and the Southern provincial council, the tourism development projects developed tourism infrastructures in 2013. The Madunagala Hot Water Spring Park was established with a perfect site planning comprising a children park, a bird park, a herbarium, a aquarium, an outside vehicle park with proper parking facilities, a retail shops complex, a folk museum and the souvenir centre. These fascilities offer tourists a good travel experience in the site. When considering the local vendors selling at the roadside, they seem to have suffered from problems due to the minor attraction of tourists and economic benefits through their businesses. Lack of sales creates high competition among vendors. This high competition of the vendors during the arrival of tourists to the site, creates conflicts and tourists have to face those conflicts in the site. This paper discusses the impact of local vendors or 


\section{Original Article}

the local community's conflicts on tourists' behaviour at Madunagala Hot Spring.

The literature review of this study investigates the term "conflict". It also explains the conflicts in a tourism site, relevant parties of the conflicts and reasons. The literature study also investigates the importance of managing the attitudes towards local communities involved in the tourism industry to develop tourist satisfaction. Limited literature in the Sri Lankan context investigates the issues of lacking local community participation in tourism and improvement needs of sites with the quality of service providers, including the local host community. The literature survey does not address how those conflicts influence tourism activities of a site. The study mainly focused on filling this gap. Hence, this study focuses on identifying the background of current conflicts among local people involved in retail business in Madunagala Hot Water Spring Garden and how it influences tourists' behaviours. Through the preliminary survey, it was identified as the nature of conflicts of the site. According to the observations, local vendors' conflicts on economic benefits through retail shops influence tourists' dissatisfaction. Hence, the research has been planned based on the problem: how do conflicts among local vendors in a travel destination influence tourists' behaviours? The study questions are 1). Why do local vendors in Madunagala Hot Water
Spring Garden get involved in conflicts? 2). How do the local vendors' conflicts influence tourists' behaviour? And 3). How do the negative impacts of conflicts can be reduced?

Three objectives have been considered for this study. The first objective was to identify the reasons for conflicts of local vendors. The second objective was selected to identify how the local vendors' conflicts influence tourists' behaviours. The third objective addressed how the negative impacts of conflicts can be reduced through the study's findings.

\section{REVIEW OF LITERATURE}

Conflict is a process of an individual or among two or more groups according to Robins; Conflict is a process that begins when one party perceives that another party has negatively affected, or is about to affect negatively, something that the first party cares about (Robins, Jude and Vorha, 2017). According to Can (2005) in Yirik's study (2015), a conflict in its general meaning could be defined as a difficulty encountered by an individual or a group in the process of choosing an option and disruption in decisionmaking mechanisms as a consequence (Can, 2005).

According to George and Jones, a conflict is a struggle that arises when one person or group's goal-directed behaviours block the goal-directed behaviour of another person or group 


\section{Original Article}

(George and Jones, 2011). Two authors emphasise that a conflict occurs when another group blocks an individual or a group's goal. Kondalkar explains those groups as employer and employees, management and workers, departments, stakeholders, shareholders, producers, and customers (Kondalkar, 2007).

Different groups are often concerned about different tourism impacts (Kreag, 2001). Several researchers have done several studies to explore this topic. Gutierrez's study's findings prove that conflicts may also occur by tourist misbehaviour such as noise, disrespect to heritage or natural landscape, and increasingly scattering of communities brought by the home-sharing economy (Gutierrez et al., 2017).

Chien and Ritchie's research highlights a critical yet rarely explored tourism phenomenon: the intergroup conflicts between residents and tourists. According to the authors, social groups' influence on their members and pressure responses to rival situations, different perceptions of tourists, emotional reactions, and miscommunication due to cultural distance and tourist misbehaviour can influence tourism conflicts (Chien \& Ritchie, 2018).

Robinson (1999) provides four dimensions of tourism conflict based on culture; tourism industry-host conflicts, tourist-host conflicts, tourism-tourist conflicts and host-host conflicts (Robinson and Boniface, 1999).
At the host-host conflict level, host parties are involved with conflicts due to several reasons. When tourism's economic benefits do not distribute among stakeholders, economic benefits have been a significant subject of conflict (Yang, Ryan and Zhang, 2013).

According to Kreag, planning is essential in tourism development on reducing conflicts. Specific plans and actions can increase tourism's benefits or decrease the gravity of a negative impact (Kreag, 2001). Communities need to understand the broad scope of impacts and agree on what positive impacts to emphasise.

Curcija's study explains that the misunderstanding of benefit is a crucial issue linked with conflicts when local community members believe that they should receive more significant economic benefits from current tourism activities (Curcija, 2016). The author further investigates this scenario by describing the role of government. The author highlights that the government should launch implementation practices and supporting systems when distributing benefits among communities to reduce conflicts (ibid, 123-124).

According to Choi, keeping a balanced perception of the costs and benefits of tourism for residents is considered a significant factor in visitor satisfaction. (Choi, 2013) The author has explained the influence of positive perception and attitude of local communities on tourist 


\section{Original Article}

satisfaction and the development of a travel destination through this study.

Gunduz and Erdem have pointed out the reasons for social conflicts in tourism, including neglecting local life rules, less receptiveness of tourists on local people, low opportunities for improvements, increasing bad habits, etc. The authors have explained the significance of creating job opportunities and earning sources by tourism as an economic advantage for the local society evaluated in this study (Gunduz \& Erdem, 2013).

The Brundtland Commission's report defined sustainable development as "development which meets the needs of current generations without compromising the ability of future generations to meet their own needs" (Our common future, 1987). The concept of sustainable development is firmly rooted in the principle that environmental protection and economic development are mutually supportive, interdependent and indivisible (Wijayadasa, 2013). The concept supports healthy economic and social development, particularly for people with a low standard of living (UNECE, 2016). Poverty, environment and development are near interconnected. Tourism can be identified as a platform that combines environmental, social and economic development. Sustainable tourism development guidelines and management practices apply to all tourism forms in all types of destinations, including mass tourism and the various niche tourism segments (UNWTO, 2016). Thus, sustainable tourism should ensure viable, long-term economic operations, providing socio-economic benefits to all legally distributed stakeholders, including stable employment and income-earning opportunities and social services to host communities, and contributing to poverty alleviation (ibid, 2016).

Sivesan (2019) has described the significance of attitude within a host community towards tourists and tourism development. The narrow thinking attitude to gain more economic benefits from tourists negatively reflects on their interactions with tourists. Therefore, the awareness of tourism of the host community is to be enhanced. According to the research, Sri Lanka tourism has lacked community participation for two main reasons: a few communities-based tourism projects run by Sri Lanka Tourism Development Authority and limited power delegated to local people. In the same study, the author has given suggestions to enhance local communities' participation in Sri Lankan tourism by educating the local community about the significance of the tourism industry and industryrelated legislation. Still, the study has not investigated the factors on conflicts of local communities and their influence on tourist satisfaction.

The recent study done by Subasinghe, Ranasinghe and Herath (2021) has elaborated the significance of 


\section{Original Article}

Mahapalassa (Madunagala) hot springs as a potential to be developed as a geo-tourism destination. The researcher has highlighted the importance of place management in geo sites. private, public or voluntary organisations may provide better service for tourists to enhance their satisfaction. Based on the findings, the author has emphasised that the Madunagala site represents the first level of a tourism destination life cycle in the exploration level. Therefore, qualitative destination services are to be developed in the sites. According to the authors, the recent site developments are not adequate to attract international tourists, and the quality of the community is also to be improved. The current study has not described any clues on conflicts among local communities and tourist satisfaction.

The reviewed literature explains the meaning and nature of conflicts in a tourism site, the relevant parties of conflicts and their causes. Although many previous studies emphasise managing the attitudes of stakeholders of the tourism industry, they do not adequately address the managing of the influence of the conflict on tourism activities of a site. Since the theoretical idea has been absorbed in the local research, there is a gap in applying conflict management in the local tourism site. Hence, this study mainly focused on filling this gap.

\section{RESEARCH METHODOLOGY}

The background of this study is based on sensitive and emotionally charged topics such as conflicts and human behaviours. Therefore, this study has been conducted using the qualitative method as an approach. Under the qualitative approach, interviews with participants and participatory field observations have been used for data collection. A purposeful sampling technique was adopted to select respondents for the interviews based on the research question. The sample includes two groups: vendors directly involved with conflicts and domestic tourists who face conflicts during their visit. The unstructured interview method has also been applied to conduct personal interviews since it is more flexible and depends on the respondents' answers. Respondents were allowed to express their ideas, and the researcher recorded their statements by documentation. The information saturation reached 17 personal interviews of vendors among 27 shops located at the Madunagala Hot Water Spring Park and 14 personal interviews with domestic tourists. All 17 vendors were women, and among 14 domestic tourists, 6 were women, while eight men were interviewed to collect data. Besides, reported data were analysed by classifying, summarising and tabulating under the content analysing technique. 


\section{Original Article}

\section{RESULTS AND DISCUSSIONS}

Madunagala Hot Water Spring Garden includes two blocks. The main block includes the hot water spring with all tourist facilities such as bathing facilities, safety changing rooms, completed washrooms with sanitary facilities, and printed information regarding the hot water spring's physical and chemical properties (Hot water Wells in Madunagala, 2013). Hot water bathing is the site's main tourist activity. In addition, there are activities, especially for children in the children park and fish and bird watching at the aquarium and the bird park. Natural landscaping can be identified as one plus point of this block.

The second block, identified as Block-B, is the allocated separate area to the permanent building and houses 27 shops/stalls. At GateB, there are 08 temporary stalls made by woods and other temporary materials. Vehicle parking area (no. 5 of the map) includes separate areas for three-wheelers, buses, vans, cars and lorries. The space in front of building no.1 has been allocated for motorcycle parking. Gate $B$ is the only exit from the vehicle park, which links to Block- A through Gate A. Hence, all tourists go through Gate B to reach hot water springs, and it has given a chance for the temporary stalls to attract the majority of them with no issues. Shop holders in the permanent building, specially mentioned by no.6 in the map, have to make massive competition with others to earn a considerable income per day.
Map 1: The Site map of Madunagala Hot Water Spring Garden

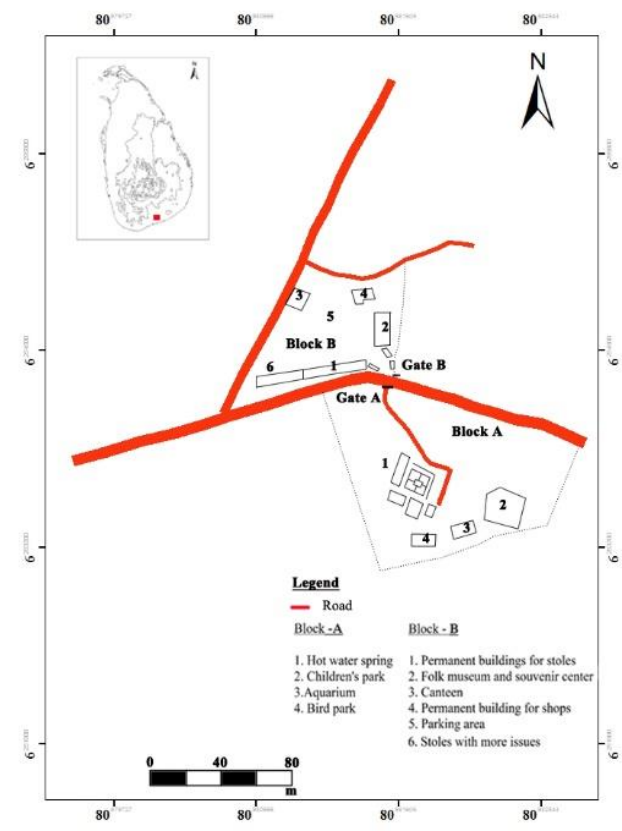

Madunagala hot water spring garden

Reasons for the conflicts between shop holders

\section{Limited time for sales}

The majority of shop holders are women, and their husbands involve in farming and Chena cultivation in the daytime. "Some of us work either in farm/Chena or home. When a tourist team comes to the site, we get the message, and we come and open our shops" (personal communication, 10 December, 2016 at Madunagala Hot water spring Area). According to the findings through the interviews done with shop holders, whenever they are free from their farming activities in the cultivations and household activities such as cooking, leading children to their 


\section{Original Article}

schools, they open their shops. When they open their shops, the competition begins among other shops. This competition increases until conflicts occur among them.

\section{Selling same products in the majority of shops}

Both temporary and permanent shop owners sell the same categories of products in their stalls. Permanent shop owners try to sell more soft cool drinks, snacks, sweetmeats, toys and food (Coconut roti (coconut flatbread), manioc, rice \& curry, corn and short eats) and beverages (rice flake porridge, bran porridge, Belimal water (The Flowers of Bael), plane tea, king coconut/Kurumba, orange juice) than temporary shop owners in their stalls. According to the capabilities of their shops, they can store their items. Temporary shop owners do not have this opportunity to store their selling items. Hence, they try to sell only products such as grains (mung, bran, millet, cowpea, corn), vegetables (pumpkin, beans, brinjal, snake beans, cucumber) and fruits (watermelon, mango, orange, banana) from their cultivations or which are supplied by others for the same minimum price. All the shop owners sell these kinds of similar products, and they do not hesitate to bargain their prices rather than other shop owners' when customers ignore and pass their shops. According to the 3-day field observations, this bargaining has become a reason for quick and sudden conflicts among neighbouring shop owners.

\section{Location issues of the establishments}

The location of building allocated for permanent shops and involvement of temporary shop owners are other issues. As the map shows, the building with permanent shops is located far from the vehicle park, due to which the permanent shops do not attract the majority of tourists However, the temporary shops have been built near Gate B, through which all tourists pass when they exit to the vehicle park and walk to the hot water spring park. The temporary shop owners have built their temporary stalls with a minimum cost, using natural materials such as coconut and palm leaves, straw and wood. According to the observation, they sell farm products which can be found without any cost. As a result, it is easier for them to get benefits rather than permeant shop owners. Due to the temporary arrangements of their stalls, they are not required to pay taxes, but the permanent shop owners have to pay a monthly tax to the government for the building even if they cannot earn a profitable income. When temporary shop owners earn a higher income without any taxes than permanent shop holders, it seems that they are not ready to accept that condition. According to the 17 respondents of vendors, monthly paying taxes for permanent stalls, expenditures for buying items, and less economic benefits or income from the business are the key issues they face. 


\section{Original Article}

According to the participants' comments, temporary shop owners benefit from their business without paying taxes and a cost for selling items. This scenario in the Sri Lankan context is similar to Curcija's study (Curcija, 2016).

Table 1: Issues of permanent shop owners

\begin{tabular}{lll}
\hline $\begin{array}{l}\text { Permanent shops } \\
\text { holders }\end{array}$ & $\begin{array}{l}\text { Temporary shops } \\
\text { holders }\end{array}$ \\
\hline $\begin{array}{l}\text { Shops are located far } \\
\text { from tourists (vehicle }\end{array}$ & $\begin{array}{l}\text { Shops are located } \\
\text { varking close to the } \\
\text { Museum and Gate- B), }\end{array}$ & $\begin{array}{l}\text { B, Map 1) } \\
\text { tourists (at the gate- }\end{array}$ \\
Low tourist attraction & $\begin{array}{l}\text { High } \\
\text { attraction tourist }\end{array}$ \\
Low income & High income
\end{tabular}

High Taxes (over Low taxes (less than 1000.00 Rs per month) 1000.00 Rs. Per month)

High cost for Minimum expenditures expenditures

\begin{tabular}{ll}
$\begin{array}{l}\text { High competition for } \\
\text { selling }\end{array}$ & $\begin{array}{l}\text { Minimum } \\
\text { competition for } \\
\text { selling }\end{array}$ \\
\hline
\end{tabular}

Source: Author's survey Data

\section{Lack of tourists during off-seasons}

The Madunagala Hot Water Spring Garden primarily attracts domestic tourists rather than foreign tourists. Generally, April to August and December are ideal for businesses with more domestic tourists than the other months (personal communication, 13 December 2016 at Madunagala Hot water spring Area). Tourists and sellers directly meet each other at the vehicle park, and tourists automatically become the subject of the competition.
According to the sellers' view, they want to earn a profit per day as they waste time at shops. "Some days we just waste time in our shops, nobody comes and we earn no money even though we wait here" (personal communication, 11. December 2016 at Madunagala Hot water spring Area).

\section{The nature of clashes among residents or shop owners}

The nature of competition of the shop holders shows the shape of the conflict that occurs among them. This situation can be seen in several ways as follows: When a tourist group comes in a small vehicle such as motor bicycle, tuk-tuk or motor car, the shop owner goes to them and invites them to park their vehicle at their shops and promises to protect the vehicle until they come back. Then, they keep conversation with the visitor and invite and motivate them to buy some things from their stalls. Suppose the tourist or the visitor is not interested in buying anything. In that case, they start to say grievances with him like, "Please buy something from us/ still we do not have an income for today/ Think about us too! / everybody just passing us" (Field observations personal communication, $12^{\text {th }}$ December 2016 at Madunagala Hot water spring Area).

When a tourist/customer buys something, shop owners compel him or her to buy more things. Other shop owners also try to follow and sell the same thing for the same person. This creates an uncomfortable and 


\section{Original Article}

embarrassing environment for the tourist. They (temporary shop holders) then criticise other shop holders (temporary shop holders and shop holders can attract more tourists in front of tourists). When these incidents grow into their peak levels, the shop owners rebuke other shop owners and make them sarcastic in front of customers/ tourists. In such situations, tourists hesitate to stay in the area and try to leave the place. This competition or conflict is directly linked with customer dissatisfaction at the site, and the following topics discuss it.

Table 2: Nature of competition

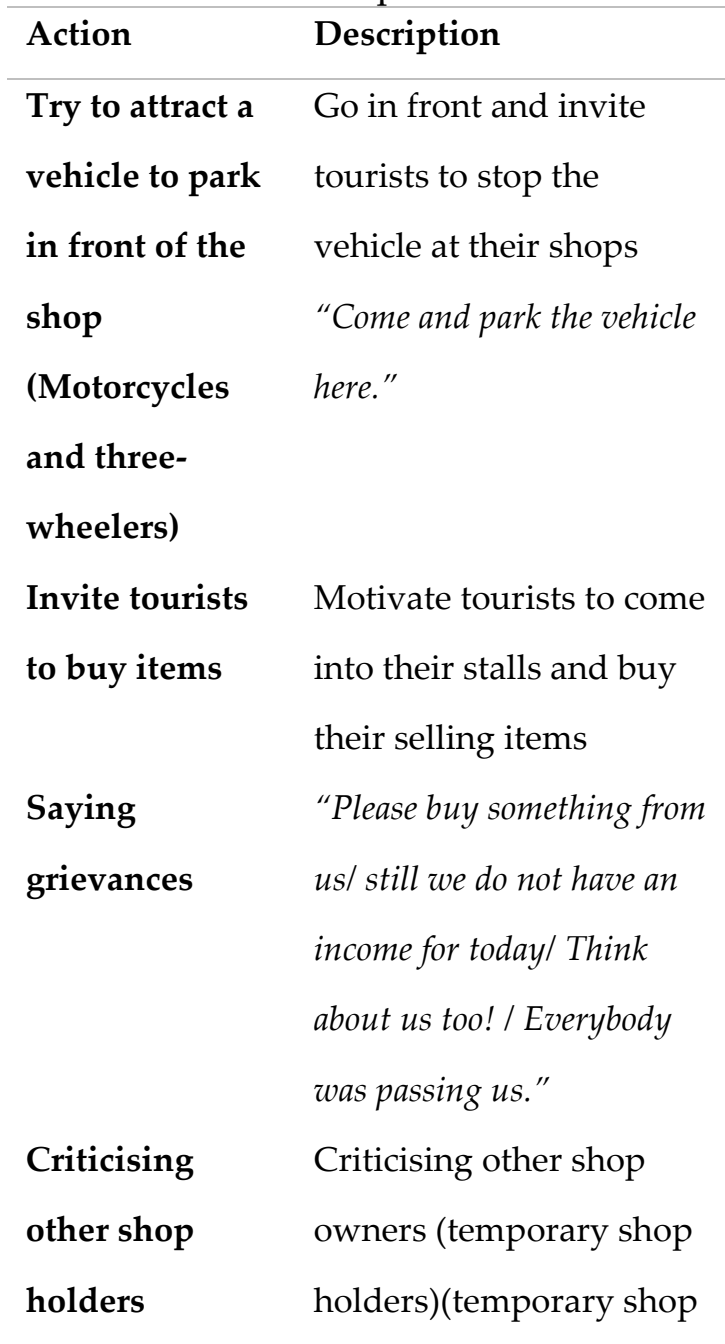

holders and permanent shop holders) can attract more tourists in front of tourists.

Try to sell more When a tourist/customer items for one buys something, he/she is person asked to buy more and more things. Other shop owners also try to follow and sell the same thing for the same person.

Rebuke other The peak of competition; shop owners/ Rebuking other shop Making owners and making sarcastic comments sarcastically in comments front of customers/ tourists

Source: author's observation of the survey Table 2 explains the expansion of vendors' reactions when tourists visit the site and how those competitive reactions convert into conflicts. According to the observation during the study, conflicts occur in front of tourists.

\section{Perceptions and reactions of tourists regarding the conflicts of vendors}

\section{Tourists' view regarding conflicts}

According to the standard view of tourists, they see this competition as trouble at the site. "No escape from others when we visit one shop", "Who brings money to buy items from all sellers here?" It should be noted here that out 


\section{Original Article}

of 14 visitors/tourists who were interviewed, six of them came up with the same notion that clearly shows the real and exact meaning of the above statements. These six respondents consider those conflicts as harassment which limits their freedom to visit the site. According to this perception, these tourists do not try to visit any shops and try to leave the place, bypassing the shopping area. This scenario shows that vendors' behaviours have had a negative impact on almost the majority.

\section{Tourists' view on vendors' behaviours}

Five tourists (including one person from the six visitors mentioned above) have understood sellers' situation, including sellers' poverty, low educational levels, and dissatisfaction with their competitive behaviours. "Purposely they do not want to trouble us, they just want to earn an income but, they do not know how to do that" (personal communication, $11^{\text {th }}$ December 2016 at Madunagala Hot water spring Area). The unstructured interviews focused on investigating those tourists' reactions to behaviours when they visit them. According to the views given by five tourists, vendors are friendly, and their reactions can be appreciated but, facing vendors' conflicts was a negative experience. This category of tourists tries to buy something from several shops, and some in groups visit several shops.

Three tourists among 14 carried neutral views of vendors' behaviours. According to the observation, they did not visit the shops. These tourists did not want to engage with another two parties' conflict. "That is their matters, we do not want to see them" (personal communication, 12 December 2016 at Madunagala Hot water spring Area). The comment explains the abovementioned idea.

\section{Other reasons for the minor attraction of tourists}

The unstructured interviews and field observations further focused on studying tourist behaviours. Skipping shops without visiting, visiting shops but, buying nothing, visiting shops and buying products after bargaining, visiting shops and buying without bargaining are the commonly observed tourists' behaviours. Vendors with permanent shops have fewer tourist attractions, and they are not satisfied with their earnings, and are unhappy when tourists skip them. When the diversity of selling items is concerned, the temporary shop owners can sell more natural and specified products in the area such as vegetables, fruits, and grains. However, permanent shop owners sell more core products such as soft drinks (Coca-Cola, Pepsi, Fanta, Cream soda, etc.), sweetmeats, toys and ornaments from suppliers in the nearest city, Sooriyawewa or Embilipitiya. Besides, their expenditures are higher than those of the temporary shop owners. When the 17 permanent shops sell the same products, tourists are not interested in walking to the shops far from the vehicle park. In this situation, the 


\section{Original Article}

permanent shops mentioned byNno.6 in Map No.01 are at risk of attracting tourists and selling products. According to this scenario, vendors' conflicts are not the only reason why fewer tourists visit permanent shops. It was observed through the field observations that the temporary shop owners have a variety of cultivation products that the people in the area specialize in. Therefore, temporary shops attract tourists when they keep packed grains, vegetables and fruits.

\section{CONCLUSION}

This study shows that the local communities/vendors of the tourist site at Madunagala Hot Water Spring cannot gain good economic benefits from their retail shops due to limited time for sales, selling same products in the majority of shops, locations of the establishments and lack of tourists during off-seasons. As a result, they have to be involved in competitive selling activities, which then creates conflicts. Tourists, as stakeholders in the tourism industry, have to face those conflicts when they visit shops. This creates in most tourists a negative impression regarding conflicts, which leads them to skip vendors; therefore, vendors risk losing their customers due to conflicts. However, $35 \%$ of tourists of the sample have carried positive viewpoints about vendors with an understanding of their situation and willing to help them by buying products. It can be suggested that the tourism managers and policymakers should pay thorough attention to the problems caused by conflicts in tourism sites considering the positive feedback of the tourists.

\section{RECOMMENDATIONS}

Through this case study, the following recommendations can be suggested to reduce conflicts among local vendors or shop owners at Madunagala Hot Water Spring Park;

1. Introducing product diversification and motivating each vendor to sell several unique products such as grains, vegetables, and local foods in their shops.

i. Categorise shops according to products and motivate vendors to sell products according to the classification. For example, Shop 01- Food and Beverage,

ii. Shop 02-Chena products,

iii. Shop 03- vegetables, etc. Through this practice, each vendor will attract a sufficient number of tourists as per their needs.

2. Motivate vendors to sell new products such as handicrafts and souvenirs to attract visitors. When vendors can get a sufficient number of tourists, they will increase their economic benefits. When they fulfil this, conflicts will be reduced.

3. Provide adequate training for local vendors about tourism and marketing techniques to attract more customers and reduce conflicts. 


\section{Original Article}

4. Residents should not be neglected by tourists when they visit the site; therefore, tourists' attitudes should be developed to support local vendors.

5. Tourists should be motivated to buy local vendors' products to empower them.

6. Motivate researchers to conduct further studies on these issues related to local communities and tourism.

Through these recommendations, the researcher expects to reduce conflicts in the site and apply these practices to ensure tourism sustainability.

\section{Acknowledgement}

Special thanks should go to $\mathrm{Mr}$. Dhanusha Premaratne, Senior Lecturer at the University College of Ratmalane of the University of Vocational Technology for the great support and assistance in collecting the field data and data analysing.

\section{References}

Ashley, C. \& Dilys, R. (1998). Enhancing community involvement in wildlife tourism: issues and challenges. International Institute for Environment and Development.

Chien, P. M., \& Ritchie, B. W. (2018). Understanding intergroup conflicts in tourism. Annals of Tourism Research, 72, 177-179.

https://doi.org/10.1016/j.annals.2018.03.0 04

Choi, S. H. (2013). The Impacts of Tourism and Local Residents' Support on Tourism Development: A Case Study of the Rural Community of Jeongseon, Gangwon
Province, South Korea. AU-GSB EJOURNAL, 6(1), 73-82. http://www.assumptionjournal.au.edu/i ndex.php/AU-GSB/article/view/465

Curcija, M. (2016). Conflict Management within the Context of Community Based Tourism: An Exploratory Study [Doctoral dissertation, University of Queensland] https://espace.library.uq.edu.au/data/U Q_404025/s4090223_final_thesis.pdf?

George, J. M., \& Jones, G. R. (2012). Understanding and managing organizational behavior (6th ed.). Pearson Education.

Gunduz, E., \& Erdem, R. (2013, November 1). Is there a conflict between local communities and tourism? Mardin Sample. Ideas.repec.org.

https://ideas.repec.org/p/wiw/wiwrsa/er sa13p1233.html $\backslash$

Gutiérrez, J., García-Palomares, J.C., Romanillos, G. \& Salas-Olmedo, M.H. (2017). The eruption of Airbnb in tourist cities: Comparing spatial patterns of hotels and peer-to-peer accommodation in Barcelona. Tourism Management, 62 (1), 278-291.

Iran Nomad Tours. (2019, October 30). Impact of Tourism on Local Community. https://nomad.tours/ecoutourismiran/11638/impact-of-tourism-on-localcommunity

Kondalkar, V. G. (2007). Organizational behaviour. New Age International (P) Limited, Publishers.

Kreag, G., \& Grant. I. (2001). The impacts of tourism. Sea Grant Minnesota.

Luck, M. (2005). Sustainable development of tourism: a compilation of good practices World Tourism Organization. Tourism Management, 26(4), 633-634. https://doi.org/10.1016/s02615177(04)00066-4

Nagarjuna, G. (2015). Local Community Involvement in Tourism: A Content Analysis of Websites of Wildlife Resorts. Atna - Journal of Tourism Studies, 10(1), 1321. https://doi.org/10.12727/ajts.13.2 


\section{Original Article}

Ranasinghe, R., Kumudulali, U., \& Kaumadi Ranaweera, A. (2019). The role of park attributes in visitor satisfaction: evidence from Minneriya National Park in Sri Lanka. Journal of Sustainable Tourism and Entrepreneurship, 1(2). https://doi.org/10.35912/joste.v1i2.218

Robbins, S. P., Judge, T., Millett, B., \& Boyle, M. (2017). Organisational behaviour. N.S.W. Pearson Australia.

Sivesan, S. (2019). Challenges of sustainable tourism in ancient cities: a case study based on Kandy, Sri Lanka. Journal of Business Studies, 6(1), 57.

UNEC. (n.d.). United Nations Economic Commission for Europe Background Guide 2021. November 7, 2021, from https://www.nmun.org/assets/document s/conference-archives/newyork/2021/ny21-bgg-unece.pdf

Wd eranga. (2021). Telegraph Plant. [Video]. YouTube.

https://www.youtube.com/channel/UCe 4mg5PitmZV3Nn5-GihxXw

Wijayadasa, K.H. J. (2012). Governance, heritage, and sustainability. Sarasavi Publishers.

World Commission on Environment and Development. (1987). Report of the World Commission on Environment and Development: Our Common Future Towards Sustainable Development 2. Part II. Common Challenges Population and Human Resources $4 . \quad$ http://www.undocuments.net/our-common-future.pdf

Yang, J., Ryan, C., \& Zhang, L. (2013). Social conflict in communities impacted by tourism. Tourism Management, 35, 82-93. https://doi.org/10.1016/j.tourman.2012.06 .002

Yirik, E., Yõldõrõm, B., \& Çetinkaya, N. (n.d.). A study on conflict management and conflict resolution in hospitality organizations. In International Journal of Arts \& Sciences. http://universitypublications.net/ijas/080 8/pdf/F5N134.pdf 